\title{
Evaluation of the stability of reference genes in bone mesenchymal stem cells from patients with avascular necrosis of the femoral head
}

\author{
X.N. Wang ${ }^{1}$, Q.W. Yang ${ }^{2}$, Z.W. Du ${ }^{1}$, T. Yu ${ }^{1}$, Y.G. Qin ${ }^{1}$, Y. Song ${ }^{1}$, M. Xu ${ }^{1}$ \\ and J.C. Wang ${ }^{1}$ \\ ${ }^{1}$ Department of Orthopaedics, The Second Hospital of Jilin University, \\ Changchun, Jilin, China \\ ${ }^{2}$ China-Japan Union Hospital of Jilin University, Changchun, Jilin, China \\ Corresponding author: J.C. Wang \\ E-mail: jinchengwang2015@163.com
}

Genet. Mol. Res. 15 (2): gmr.15027926

Received October 27, 2015

Accepted January 22, 2016

Published May 25, 2016

DOI http://dx.doi.org/10.4238/gmr.15027926

\begin{abstract}
This study aimed to evaluate 12 genes (18S, GAPDH, B2M, ACTB, ALAS1, GUSB, HPRT1, PBGD, PPIA, PUM1, RPL29, and $T B P$ ) for their reliability and stability as reference sequences for real-time quantitative PCR (RT-qPCR) in bone marrow-derived mesenchymal stem cells (BMSCs) isolated from patients with avascular necrosis of the femoral head (ANFH). BMSCs were isolated from 20 ANFH patients divided into four groups according to etiology, and four donors with femoral neck fractures. Total RNA was isolated from BMSCs and reverse transcribed into complementary DNA, which served as a template for RT-qPCR. Three commonly used programs were then used to analyze the results. Reference gene expression varied within each group, between specific groups, and among all five groups. Based on comparisons of all five groups, two of the programs used suggested that HPRT1 was the most stable reference gene, while $18 \mathrm{~S}$ and $A C T B$ were the most variable. Among the 12 candidate reference genes, HPRT1 exhibited the greatest reliability, followed by PPIA.
\end{abstract}


Thus, these sequences could be used as references for the normalization of RT-qPCR results.

Key words: geNorm; Avascular necrosis of the femoral head; NormFinder; BestKeeper; Bone mesenchymal stem cell; Reference gene

\section{INTRODUCTION}

Avascular necrosis of the femoral head (ANFH) is a severe disease that may lead to pain, difficulty in ambulation, or even disability in the affected limb. The incidence of ANFH in China is much higher than in Western countries. The etiology of this condition is complicated, and recent evidence suggests that bone marrow-derived mesenchymal stem cells (BMSCs) may play a rather important role in its pathogenesis (Cui et al., 1997; Hernigou and Beaujean, 1997; Hernigou et al., 1999; Suh et al., 2005; Lee et al., 2006).

Due to its high sensitivity, real-time quantitative polymerase chain reaction (RTqPCR) is commonly used to examine gene expression changes in ANFH patients of different etiologies. Using this technique, Samara et al. (2014) have shown that OPG, RANK, and RANKL may play significant roles in bone remodeling progression in the necrotic area, leading to disturbed bone homeostasis. In addition, Grässel et al. (2010) measured the expression of tissue inhibitor of matrix metalloproteinase and matrix metalloproteinases, which affect the balance between bone formation and resorption in osteonecrotic femoral head tissue. However, accurate gene expression measurement by RT-qPCR is influenced by many factors, including cell type, mRNA quality, the reagents used, and the reliability and stability of the selected reference genes.

To date, a variety of reference genes, including $18 S, T B P, G U S B, P U M 1, P B G D$, RPL29, B2M, ALAS1, PPIA, HPRT1, GAPDH, and ACTB have been used in the investigation of target gene mRNA expression levels in mesenchymal stem cells (MSCs). However, controversy remains regarding the reliability and stability of certain commonly used reference genes, glyceraldehyde-3-phosphate dehydrogenase $(G A P D H)$ and beta-actin $(A C T B)$ in particular, as they are not expressed in all cell and tissue types. Several studies have shown that some reference sequences used in MSC research, including GAPDH, ribosomal protein L13a (RPL13A), and ACTB, vary in stability between different donors, expansion conditions, and differentiation processes (Vandesompele et al., 2002; Curtis et al., 2010; Quiroz et al., 2010). Moreover, some investigations have found $18 S$ to be the most unstable reference gene (Minervini et al., 2009; Cai et al., 2014). To our knowledge, there have been no studies of stable reference genes in MSCs of ANFH patients. Therefore, in the present work, we comprehensively tested the reliability of genes serving as references for expression analysis in MSCs, and identified the optimal candidates.

\section{MATERIAL AND METHODS}

\section{Cell preparation and RNA isolation}

BMSCs were obtained from the femoral heads of ANFH patients in accordance with the regulations of the Ethics Committee of the Second Hospital of Jilin University. A total of 20 
patients (average age of 52.75, ranging from 29 to 68 years) and four healthy donors (average age of 55.5, ranging from 29 to 68 years) were enrolled. The patients were divided into four groups based on ANFH etiology, with five individuals in each group: the alcohol group (group A), comprising patients with alcohol-associated ANFH (average age of 48, ranging from 42 to 59 years); the corticosteroid group (group C), comprising corticosteroid-related ANFH patients (average age of 53.8, ranging from 42 to 63 years); the trauma group (group T), comprising patients with ANFH related to trauma (average age of 54.6, ranging from 50 to 64 years); and the idiopathic group (group I), comprising patients suffering idiopathic ANFH (average age of 52.4, ranging from 40 to 65 years).

BMSCs were isolated by density gradient centrifugation and cultured in flasks with Dulbecco's modified Eagle's medium containing 10\% fetal bovine serum. BMSCs were harvested in passage one. Cells were treated with trypsin-ethylenediaminetetraacetic acid and collected by centrifugation at $500 \mathrm{~g}$ for $5 \mathrm{~min}$. Total RNA was isolated from first passage cells using TRIzol reagent (Life Technologies, Auckland, New Zealand), and its concentration was determined using a NanoDrop ND-1000 spectrophotometer (NanoDrop Technologies, Wilmington, DE, USA). All samples had 260/280-nm optical density ratios between 1.9 and 2.1.

\section{Complementary DNA (cDNA) synthesis and RT-qPCR}

For cDNA synthesis, $1 \mu \mathrm{g}$ total RNA was used with an All-in-One First-Strand cDNA Synthesis Kit (GeneCopoeia, Rockville, MD, USA) following the manufacturer protocol, and RT-qPCR was performed using All-in-One qPCR Mix (GeneCopoeia). Primers for the 12 candidate reference genes were synthesized by Sangon (Shanghai, China; Table 1). Amplification was performed using 40 cycles of $95^{\circ} \mathrm{C}$ for $20 \mathrm{~s}, 55^{\circ} \mathrm{C}$ for $20 \mathrm{~s}$, and $72^{\circ} \mathrm{C}$ for 60 $\mathrm{s}$. The melting curve were performed for confirming specificity of the product.

\begin{tabular}{|c|c|c|}
\hline Symbol & Name & Primer sequences \\
\hline $18 S$ & 18S ribosomal RNA & $\begin{array}{l}\text { F: CGGCTACCACATCCAAGGAA } \\
\text { R: GCTGGAATTACCGCGGCT }\end{array}$ \\
\hline$\overline{G A P D H}$ & Glyceraldehyde-3-phosphate dehydrogenase & $\begin{array}{l}\text { F: GACAGTCAGCCGCATCTTCT } \\
\text { R: TTAAAAGCAGCCCTGGTGAC }\end{array}$ \\
\hline$\overline{B 2 M}$ & Beta-2 microglobulin & $\begin{array}{l}\text { F: AGCGTACTCCAAAGATTCAGGTT } \\
\text { R: ATGATGCTGCTTACATGTCTCGAT }\end{array}$ \\
\hline$\overline{A C T B}$ & Actin, beta & $\begin{array}{l}\text { F: AGAAAATCTGGCACCACACC } \\
\text { R: TAGCACAGCCTGGATAGCAA }\end{array}$ \\
\hline$\overline{A L A S 1}$ & Delta-aminolevulinate synthase & $\begin{array}{l}\text { F: GGCAGCACAGATGAATCAGA } \\
\text { R: CCTCCATCGGTTTTCACACT }\end{array}$ \\
\hline$\overline{G U S B}$ & Glucuronidase, beta & $\begin{array}{l}\text { F: AGCCAGTTCCTCATCAATGG } \\
\text { R: GGTAGTGGCTGGTACGGAAA }\end{array}$ \\
\hline HPRT-I & Hypoxanthine phosphoribosyltransferase 1 & $\begin{array}{l}\text { F: GACCAGTCAACAGGGGACAT } \\
\text { R: CCTGACCAAGGAAAGCAAAG }\end{array}$ \\
\hline$P B G D$ & Porphobilinogen deaminase & $\begin{array}{l}\text { F: AGTGTGGTGGGAACCAGC } \\
\text { R: CAGGATGATGGCACTGAACTC }\end{array}$ \\
\hline$\overline{P P I A}$ & Peptidylprolyl isomerase A (cyclophilin A) & $\begin{array}{l}\text { F: AGACAAGGTCCCAAAGAC } \\
\text { R: ACCACCCTGACACATAAA } \\
\end{array}$ \\
\hline PUM1 & Pumilio homolog 1 (Drosophila) & $\begin{array}{l}\text { F: CAGGCTGCCTACCAACTCAT } \\
\text { R: GTTCCCGAACCATCTCATTC }\end{array}$ \\
\hline RPL29 & Ribosomal protein L29 & $\begin{array}{l}\text { F: GGCGTTGTTGACCCTATTTC } \\
\text { R: GTGTGTGGTGTGGTTCTTGG }\end{array}$ \\
\hline$T B P$ & TATA-box binding protein & $\begin{array}{l}\text { F: TGCACAGGAGCCAAGAGTGAA } \\
\text { R: CACATCACAGCTCCCCACCA }\end{array}$ \\
\hline
\end{tabular}




\section{Data analysis}

RT-qPCR results were analyzed by three commonly used programs: BestKeeper (Pfaffl et al., 2004), geNorm (Vandesompele et al., 2002), and NormFinder (Andersen et al., 2004). The coefficient of variation was calculated by dividing the standard deviation (SD) by the mean threshold cycle $(\mathrm{Ct})$ value. All 12 candidate reference genes were analyzed based on their stability in the five groups under investigation.

\section{RESULTS}

\section{RT-qPCR}

RT-qPCR amplification products from each reaction were verified by $1 \%$ agarose gel electrophoresis, which showed amplicons of the expected size. Moreover, melt curves revealed a single and narrow peak for each reference gene (Figure 1).
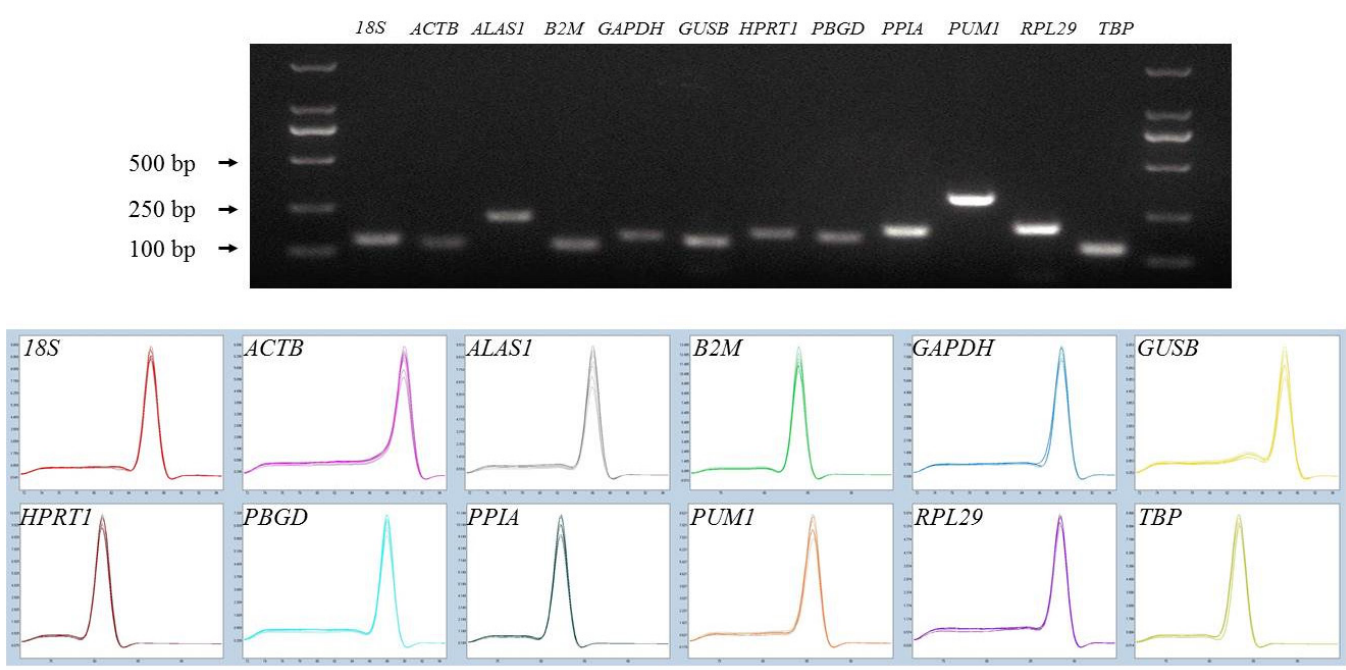

Figure 1. Specificity of primers and amplicon lengths. Images show $1 \%$ agarose gel electrophoresis of amplified fragments and melt curves of the 12 reference genes.

$\mathrm{Ct}$ values from the 24 samples ranged between 14.6 and 38.0 (Table 2). Of the 12 reference genes among the five groups, $18 \mathrm{~S}$ demonstrated the most variable results, with the highest SD (4.5). In contrast, $P B G D$ showed the lowest SD (1.86; Figure 2).

\section{BestKeeper analysis}

Since BestKeeper can only analyze up to 10 reference genes (Pfaffl et al., 2004), the two least stable sequences ( $18 S$ and $A C T B$ ) were removed (Table 3). PPIA, PBGD, B2M, and PPIA were determined to be the most stable genes in groups $\mathrm{A}, \mathrm{C}, \mathrm{I}$, and T, respectively, 
while $A L A S 1$ demonstrated the highest stability in the control group. Two-group comparisons produced variable results concerning the most stable reference gene, although PPIA was most frequently the highest ranked in such analyses. Among all five groups, BestKeeper analysis revealed HPRT1 to be the most stable, followed by PPIA and RPL29.

\begin{tabular}{|c|c|c|c|c|c|c|c|c|c|c|c|c|c|}
\hline Group & $\mathrm{N}=24$ & $18 \mathrm{~S}$ & GAPDH & $B 2 M$ & $A C T B$ & ALASI & GUSB & HPRT-1 & $P B G D$ & $P P I A$ & PUMI & RPL29 & $T B P$ \\
\hline \multirow[t]{6}{*}{ Alcohol } & Mean & 26.8 & 25.3 & 27.5 & 25.7 & 29.4 & 32.6 & 31.2 & 34.0 & 27.1 & 31.1 & 32.4 & 30.5 \\
\hline & Max & 31.2 & 32.4 & 33.7 & 33.7 & 31.5 & 33.5 & 35.7 & 37.5 & 33.4 & 32.7 & 38.0 & 32.8 \\
\hline & Min & 22.8 & 22.6 & 25.2 & 22.7 & 26.9 & 31.7 & 28.2 & 32.1 & 23.6 & 28.5 & 28.9 & 28.5 \\
\hline & Max-Mean & 4.4 & 7.2 & 6.2 & 7.9 & 2.0 & 0.9 & 4.5 & 3.5 & 6.3 & 1.5 & 5.5 & 2.3 \\
\hline & \begin{tabular}{|l|} 
Mean-Min \\
\end{tabular} & 4.1 & 2.7 & 2.3 & 3.0 & 2.5 & 0.9 & 3.0 & 1.9 & 3.5 & 2.7 & 3.5 & 2.0 \\
\hline & SD & 3.4 & 3.7 & 3.3 & 4.2 & 1.5 & 0.5 & 2.5 & 1.9 & 3.5 & 1.2 & 3.2 & 1.2 \\
\hline \multirow[t]{6}{*}{ Corticosteroid } & Mean & 25.5 & 23.5 & 25.9 & 23.5 & 29.5 & 32.3 & 30.8 & 33.6 & 25.9 & 30.9 & 31.8 & 30.6 \\
\hline & Max & 30.6 & 25.9 & 29.3 & 25.7 & 31.4 & 35.7 & 33.6 & 37.4 & 30.9 & 32.3 & 34.3 & 33.4 \\
\hline & Min & 18.6 & 20.8 & 23.0 & 20.4 & 26.5 & 28.7 & 28.7 & 29.7 & 22.8 & 27.7 & 29.5 & 27.8 \\
\hline & \begin{tabular}{|l|} 
Max-Mean \\
\end{tabular} & 5.1 & 2.5 & 3.4 & 2.2 & 1.9 & 3.4 & 2.8 & 3.8 & 4.9 & 1.4 & 2.5 & 2.8 \\
\hline & Mean-Min & 6.9 & 2.7 & 2.9 & 3.1 & 3.0 & 3.5 & 2.1 & 3.9 & 3.1 & 3.3 & 2.2 & 2.8 \\
\hline & SD & 4.7 & 1.8 & 1.9 & 1.8 & 1.6 & 2.1 & 1.7 & 2.3 & 2.2 & 1.5 & 1.6 & 1.6 \\
\hline \multirow[t]{6}{*}{ Idiopathic } & Mean & 25.0 & 24.3 & 26.9 & 24.3 & 30.7 & 33.1 & 31.5 & 33.1 & 26.2 & 31.8 & 32.5 & 31.5 \\
\hline & Max & 31.3 & 29.6 & 32.6 & 28.0 & 36.3 & 37.6 & 35.9 & 35.9 & 31.3 & 35.8 & 37.7 & 35.9 \\
\hline & Min & 18.8 & 21.5 & 23.7 & 20.9 & 27.5 & 29.7 & 29.1 & 30.0 & 23.3 & 27.9 & 29.6 & 28.6 \\
\hline & Max-Mean & 6.4 & 5.3 & 5.7 & 3.7 & 5.6 & 4.5 & 4.4 & 2.8 & 5.2 & 4.0 & 5.1 & 4.3 \\
\hline & \begin{tabular}{|l|} 
Mean-Min \\
\end{tabular} & 6.2 & 2.7 & 3.2 & 3.4 & 3.2 & 3.4 & 2.4 & 3.1 & 2.8 & 3.9 & 2.9 & 2.9 \\
\hline & SD & $\begin{array}{lll}4.4 \\
\end{array}$ & 2.5 & 3.0 & 2.1 & 2.8 & 2.5 & 2.5 & 2.0 & 2.6 & 2.8 & 2.7 & 2.7 \\
\hline \multirow[t]{6}{*}{ Trauma } & Mean & 27.2 & 26.2 & 29.4 & 26.9 & 33.0 & 33.9 & 33.4 & 33.9 & 29.1 & 33.2 & 34.0 & 32.9 \\
\hline & Max & 33.4 & 31.7 & 35.8 & 33.5 & 37.7 & 36.8 & 35.7 & 36.5 & 32.6 & 36.8 & 35.9 & 37.7 \\
\hline & Min & 22.4 & 23.6 & 25.8 & 24.2 & 30.5 & 32.2 & 31.0 & 33.4 & 26.2 & 31.4 & 32.1 & 31.0 \\
\hline & \begin{tabular}{|l|} 
Max-Mean \\
\end{tabular} & 6.2 & 5.4 & 6.4 & 6.7 & 4.6 & 2.9 & 2.2 & 2.6 & 3.5 & 3.5 & 1.9 & 4.8 \\
\hline & \begin{tabular}{|l|} 
Mean-Min \\
\end{tabular} & 4.8 & 2.7 & 3.6 & 2.6 & 2.6 & 1.7 & 2.5 & 0.5 & 2.9 & 1.8 & 1.9 & 1.9 \\
\hline & SD & 4.3 & 3.3 & 3.7 & 3.4 & 2.9 & 1.8 & 1.9 & 0.9 & 2.6 & 2.0 & 1.3 & 2.6 \\
\hline \multirow[t]{6}{*}{ Control } & Mean & 23.8 & 23.0 & 25.3 & 23.2 & 28.7 & 32.2 & 29.2 & 30.9 & 24.4 & 29.7 & 30.2 & 29.4 \\
\hline & Max & 30.5 & 25.3 & 27.8 & 26.5 & 30.8 & 35.5 & 30.4 & 33.4 & 25.8 & 31.7 & 31.3 & 32.4 \\
\hline & Min & 14.6 & 21.4 & 22.6 & 19.8 & 26.7 & 30.4 & 27.4 & 29.1 & 22.5 & 28.0 & 28.2 & 26.4 \\
\hline & \begin{tabular}{|l|} 
Max-Mean \\
\end{tabular} & 6.8 & 2.3 & 2.5 & 3.4 & 2.0 & 3.3 & 1.3 & 2.6 & 1.3 & 2.0 & 1.1 & 3.1 \\
\hline & \begin{tabular}{|l|} 
Mean-Min \\
\end{tabular} & 9.2 & 1.6 & 2.7 & 3.4 & 2.1 & 1.8 & 1.8 & 1.7 & 2.0 & 1.7 & 2.0 & 2.9 \\
\hline & SD & 5.8 & 1.4 & 1.6 & 2.2 & 1.4 & 1.6 & 1.0 & 1.7 & 1.1 & 1.2 & 1.2 & 2.0 \\
\hline
\end{tabular}

$\mathrm{SD}=$ standard deviation.

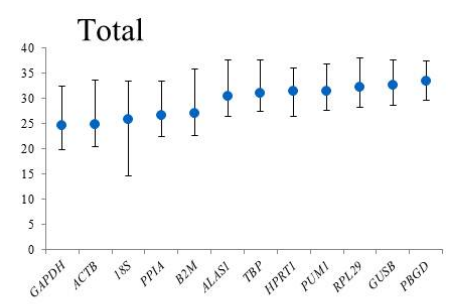

$\mathrm{T}$

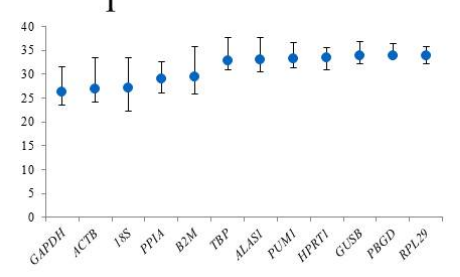

A

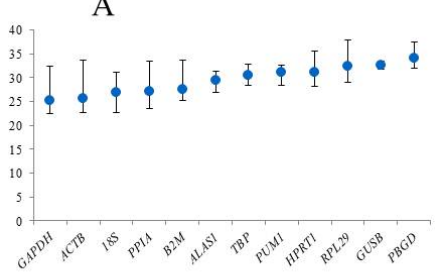

I

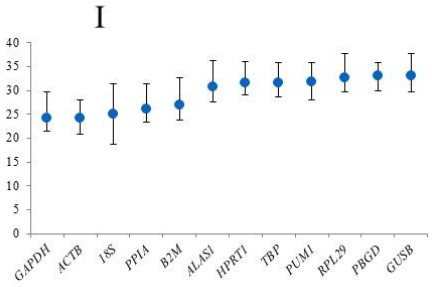

$\mathrm{C}$
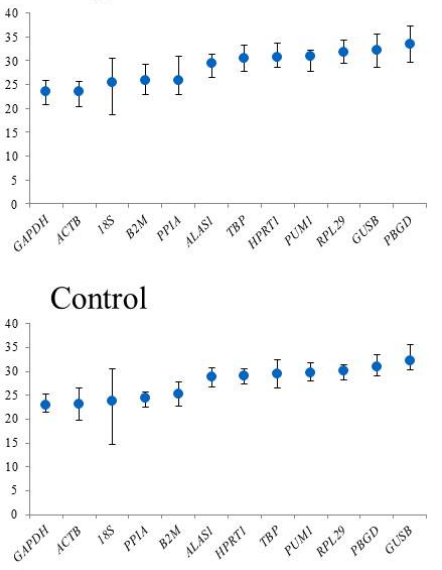

Figure 2. Mean $\mathrm{Ct}$ values of all 12 candidate reference genes from all 24 samples. (A) Alcohol group, (C) corticosteroid group, (I) idiopathic group, (T) trauma group. Data are reported as means \pm standard deviations. 
Table 3. Stability rank of candidate reference genes according to BestKeeper analysis.

\begin{tabular}{l|c|c|c|c|c|c|c|c|c|c|c|c|c|c|c|c}
\hline Gene & $\begin{array}{c}\text { All groups } \\
\text { rank }\end{array}$ & $\begin{array}{c}\mathrm{A} \\
\text { rank }\end{array}$ & $\begin{array}{c}\mathrm{C} \\
\text { rank }\end{array}$ & $\begin{array}{c}\mathrm{I} \\
\text { rank }\end{array}$ & $\begin{array}{c}\mathrm{T} \\
\text { rank }\end{array}$ & $\begin{array}{c}\text { Control } \\
\text { rank }\end{array}$ & $\begin{array}{c}\mathrm{A}-\mathrm{C} \\
\text { rank }\end{array}$ & $\begin{array}{c}\mathrm{A}-\mathrm{I} \\
\text { rank }\end{array}$ & $\begin{array}{c}\mathrm{A}-\mathrm{T} \\
\text { rank }\end{array}$ & $\begin{array}{c}\text { A-control } \\
\text { rank }\end{array}$ & $\begin{array}{c}\text { C-I } \\
\text { rank }\end{array}$ & $\begin{array}{c}\text { C-T } \\
\text { rank }\end{array}$ & $\begin{array}{c}\text { C-control } \\
\text { rank }\end{array}$ & $\begin{array}{c}\text { I-T } \\
\text { rank }\end{array}$ & $\begin{array}{c}\text { I-control } \\
\text { rank }\end{array}$ & $\begin{array}{c}\text { T-control } \\
\text { rank }\end{array}$ \\
\hline HPRT-1 & 1 & 4 & 3 & 10 & 2 & 2 & 1 & 3 & 1 & 2 & 6 & 3 & 3 & 2 & 8 & 2 \\
\hline PPIA & 2 & 1 & 7 & 2 & 1 & 3 & 2 & 4 & 2 & 1 & 5 & 1 & 7 & 1 & 2 & 1 \\
\hline RPL29 & 3 & 2 & 11 & 8 & 5 & 9 & 6 & 2 & 3 & 5 & 11 & 7 & 11 & 4 & 9 & 4 \\
\hline B2M & 4 & 7 & 5 & 1 & 11 & 6 & 4 & 1 & 5 & 4 & 1 & 5 & 5 & 11 & 1 & 6 \\
\hline ALAS1 & 5 & 8 & 4 & 11 & 3 & 1 & 7 & 8 & 6 & 8 & 4 & 2 & 1 & 3 & 3 & 3 \\
\hline GAPDH & 6 & 6 & 6 & 9 & 4 & 5 & 5 & 6 & 4 & 6 & 7 & 4 & 9 & 5 & 10 & 5 \\
\hline PUMI & 7 & 10 & 2 & 4 & 9 & 8 & 8 & 9 & 8 & 11 & 2 & 8 & 2 & 6 & 4 & 9 \\
\hline TBP & 8 & 9 & 10 & 3 & 8 & 10 & 9 & 7 & 7 & 9 & 3 & 10 & 10 & 9 & 7 & 10 \\
\hline PUSB & 9 & 11 & 9 & 5 & 7 & 7 & 10 & 10 & 10 & 10 & 8 & 9 & 6 & 7 & 6 & 8 \\
\hline ACTB & 10 & 3 & 1 & 7 & 10 & 11 & 3 & 5 & 9 & 7 & 10 & 11 & 4 & 10 & 11 & 11 \\
\hline ISS & 11 & 5 & 8 & 6 & 6 & 4 & 11 & 11 & 11 & 3 & 9 & 6 & 8 & 8 & 5 & 7 \\
\hline
\end{tabular}

$\mathrm{A}=$ Alcohol group $\mathrm{C}=$ corticosteroid group; $\mathrm{I}=$ idiopathic group; $\mathrm{T}=$ trauma group.

\section{geNorm analysis}

A reference gene with an average expression stability value $(\mathrm{M})>1.5$ was considered unreliable. As shown in Table 4, the lowest M values were demonstrated by GAPDH/B2M in groups A and C, PUM1/GUSB in group I and T. The combination PUM1/GUSB most frequently showed the lowest $\mathrm{M}$ value in comparisons between two groups. When all five groups were compared, geNorm analysis revealed that PUM1/GUSB, TBP, and HPRT1 demonstrated the greatest stability.

Table 4. Stability rank of candidate reference genes according to geNorm analysis.

\begin{tabular}{|c|c|c|c|c|c|c|c|c|c|c|c|c|c|c|c|c|}
\hline Gene & $\begin{array}{c}\begin{array}{c}\text { All groups } \\
\text { rank }\end{array} \\
\end{array}$ & $\begin{array}{c}\mathrm{A} \\
\text { rank }\end{array}$ & $\begin{array}{c}\mathrm{C} \\
\text { rank }\end{array}$ & $\begin{array}{c}\mathrm{I} \\
\text { rank }\end{array}$ & $\begin{array}{c}\mathrm{T} \\
\text { rank }\end{array}$ & \begin{tabular}{|c|}
$\begin{array}{c}\text { Control } \\
\text { rank }\end{array}$ \\
\end{tabular} & $\begin{array}{l}\mathrm{A}-\mathrm{C} \\
\text { rank }\end{array}$ & $\begin{array}{r}\text { A-I } \\
\text { rank }\end{array}$ & $\begin{array}{l}\text { A-T } \\
\text { rank }\end{array}$ & \begin{tabular}{|c|} 
A-control \\
rank
\end{tabular} & $\begin{array}{c}\mathrm{C}-\mathrm{I} \\
\text { rank }\end{array}$ & $\begin{array}{l}\mathrm{C}-\mathrm{T} \\
\text { rank }\end{array}$ & \begin{tabular}{|c|} 
C-control \\
rank
\end{tabular} & $\begin{array}{c}\mathrm{I}-\mathrm{T} \\
\text { rank }\end{array}$ & $\begin{array}{c}\text { I-control } \\
\text { rank }\end{array}$ & $\begin{array}{c}\text { T-control } \\
\text { rank }\end{array}$ \\
\hline PUMI & 1 & 10 & 3 & 1 & 1 & 4 & 2 & 8 & 1 & 10 & 4 & 1 & 2 & 1 & 3 & 9 \\
\hline$\overline{\text { GUSB }}$ & 2 & 11 & 10 & 2 & 2 & 6 & 10 & 10 & 2 & 11 & 2 & 2 & 9 & 2 & 4 & 8 \\
\hline$\overline{T B P}$ & 3 & 9 & 6 & 4 & 4 & 9 & 1 & 6 & 3 & 9 & 7 & 3 & 4 & 3 & 6 & 10 \\
\hline HPRT-1 & 4 & 6 & 5 & 9 & 5 & 7 & 5 & 3 & 4 & 6 & 6 & 5 & 3 & 5 & 9 & 6 \\
\hline RPL29 & 5 & 5 & 11 & 8 & 3 & 8 & 6 & 2 & 5 & 5 & 11 & 4 & 11 & 4 & 7 & 7 \\
\hline ALAS1 & 6 & 8 & 4 & 11 & 8 & 2 & 3 & 7 & 8 & 8 & 5 & 7 & 1 & 8 & 8 & 2 \\
\hline PPIA & 7 & 4 & 9 & 5 & 7 & 3 & 7 & 1 & 7 & 2 & 9 & 6 & 5 & 7 & 1 & 1 \\
\hline$P B G D$ & 8 & 7 & 8 & 7 & 6 & 10 & 4 & 5 & 6 & 7 & 10 & 11 & 7 & 6 & 10 & 11 \\
\hline$B 2 M$ & 9 & 2 & 2 & 3 & 11 & 5 & 8 & 4 & 10 & 3 & 1 & 10 & 8 & 11 & 2 & 5 \\
\hline GAPDH & 10 & 1 & 1 & 10 & 9 & 11 & 9 & 10 & 9 & 4 & 3 & 8 & 10 & 9 & 11 & 4 \\
\hline$A C T B$ & 11 & 3 & 7 & 6 & 10 & 1 & 11 & 11 & 11 & 1 & 8 & 9 & 6 & 10 & 5 & 3 \\
\hline $18 S$ & 12 & 12 & 12 & 12 & 12 & 12 & 12 & 12 & 12 & 12 & 12 & 12 & 12 & 12 & 12 & 12 \\
\hline
\end{tabular}

$\mathrm{A}=$ Alcohol group; $\mathrm{C}=$ corticosteroid group; $\mathrm{I}=$ idiopathic group; $\mathrm{T}=$ trauma group.

\section{NormFinder analysis}

According to NormFinder (Wen et al., 2012), the lower the stability value, the more stable the reference gene. As shown in Table 5, the most stable sequences were determined to be HPRT1 in group A (with a stability value of 0.206), PUM1 (0.323) in group C, GUSB (0.428) in group I, HPRT1 (0.355) in group T, and ALAS1 (0.115) in the control group. Among the two-group comparisons, HPRT1 most often exhibited the highest stability. In a comparison of all five groups, the top three reference genes according to stability were HPRTI, PPIA, and ALAS1. 
Table 5. Stability rank of candidate reference genes according to NormFinder analysis.

\begin{tabular}{l|c|c|c|c|c|c|c|c|c|c|c|c|c|c|c|c}
\hline Gene & $\begin{array}{c}\text { All groups } \\
\text { rank }\end{array}$ & $\begin{array}{c}\mathrm{A} \\
\text { rank }\end{array}$ & $\begin{array}{c}\mathrm{C} \\
\text { rank }\end{array}$ & $\begin{array}{c}\mathrm{I} \\
\text { rank }\end{array}$ & $\begin{array}{c}\mathrm{T} \\
\text { rank }\end{array}$ & $\begin{array}{c}\text { Control } \\
\text { rank }\end{array}$ & $\begin{array}{c}\mathrm{A}-\mathrm{C} \\
\text { rank }\end{array}$ & $\begin{array}{c}\mathrm{A}-\mathrm{I} \\
\text { rank }\end{array}$ & $\begin{array}{c}\mathrm{A}-\mathrm{T} \\
\text { rank }\end{array}$ & $\begin{array}{c}\text { A-control } \\
\text { rank }\end{array}$ & $\begin{array}{c}\text { C-I } \\
\text { rank }\end{array}$ & $\begin{array}{c}\text { C-T } \\
\text { rank }\end{array}$ & $\begin{array}{c}\text { C-control } \\
\text { rank }\end{array}$ & $\begin{array}{c}\text { I-T } \\
\text { rank }\end{array}$ & $\begin{array}{c}\text { I-control } \\
\text { rank }\end{array}$ & $\begin{array}{c}\text { T-control } \\
\text { rank }\end{array}$ \\
\hline HPRT-1 & 1 & 1 & 5 & 11 & 1 & 2 & 2 & 2 & 1 & 1 & 10 & 1 & 1 & 2 & 6 & 1 \\
\hline PPIA & 2 & 5 & 10 & 3 & 2 & 6 & 4 & 5 & 3 & 4 & 7 & 4 & 9 & 1 & 5 & 2 \\
\hline ALAS1 & 3 & 7 & 6 & 9 & 3 & 1 & 8 & 11 & 10 & 5 & 9 & 7 & 2 & 3 & 4 & 3 \\
\hline B2M & 4 & 4 & 3 & 2 & 11 & 3 & 3 & 1 & 5 & 3 & 2 & 10 & 3 & 9 & 1 & 8 \\
\hline GAPDH & 5 & 6 & 2 & 8 & 5 & 5 & 6 & 6 & 4 & 7 & 3 & 3 & 5 & 6 & 7 & 5 \\
\hline RPL29 & 6 & 3 & 11 & 10 & 4 & 9 & 5 & 4 & 2 & 6 & 11 & 5 & 11 & 4 & 11 & 4 \\
\hline$P B G D$ & 7 & 2 & 4 & 7 & 9 & 10 & 1 & 3 & 11 & 2 & 4 & 11 & 8 & 10 & 9 & 10 \\
\hline PUM1 & 8 & 9 & 1 & 5 & 8 & 8 & 7 & 8 & 7 & 10 & 1 & 2 & 4 & 8 & 8 & 9 \\
\hline GUSB & 9 & 10 & 8 & 1 & 6 & 7 & 10 & 7 & 6 & 9 & 5 & 8 & 7 & 5 & 3 & 6 \\
\hline ACTB & 10 & 11 & 7 & 4 & 7 & 4 & 11 & 9 & 8 & 8 & 6 & 9 & 6 & 7 & 2 & 7 \\
\hline TBP & 11 & 8 & 9 & 6 & 10 & 11 & 9 & 10 & 9 & 11 & 8 & 6 & 10 & 11 & 10 & 11 \\
\hline $18 S$ & 12 & 12 & 12 & 12 & 12 & 12 & 12 & 12 & 12 & 12 & 12 & 12 & 12 & 12 & 12 & 12 \\
\hline $\mathrm{A}$
\end{tabular}

$\mathrm{A}=$ Alcohol group $\mathrm{C}=$ corticosteroid group; $\mathrm{I}=$ idiopathic group; $\mathrm{T}=$ trauma group

Taking together the analyses of all three programs, $18 S$ and $H P R T 1$ were considered the least and most stable reference genes, respectively, among ANFH patients of different etiologies (Figure 3).

\section{BestKeeper}

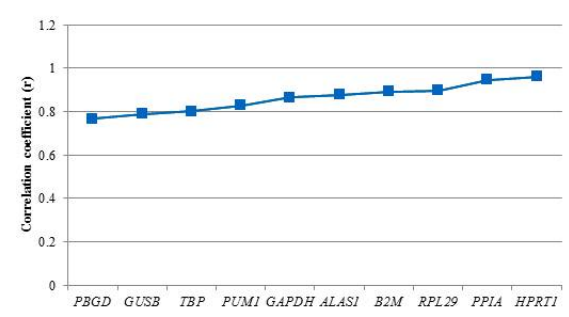

NormFinder

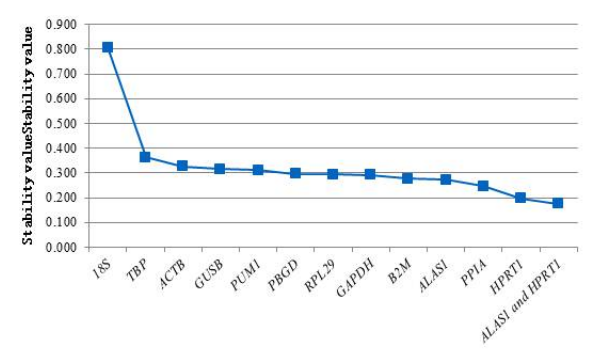

\section{GeNorm}
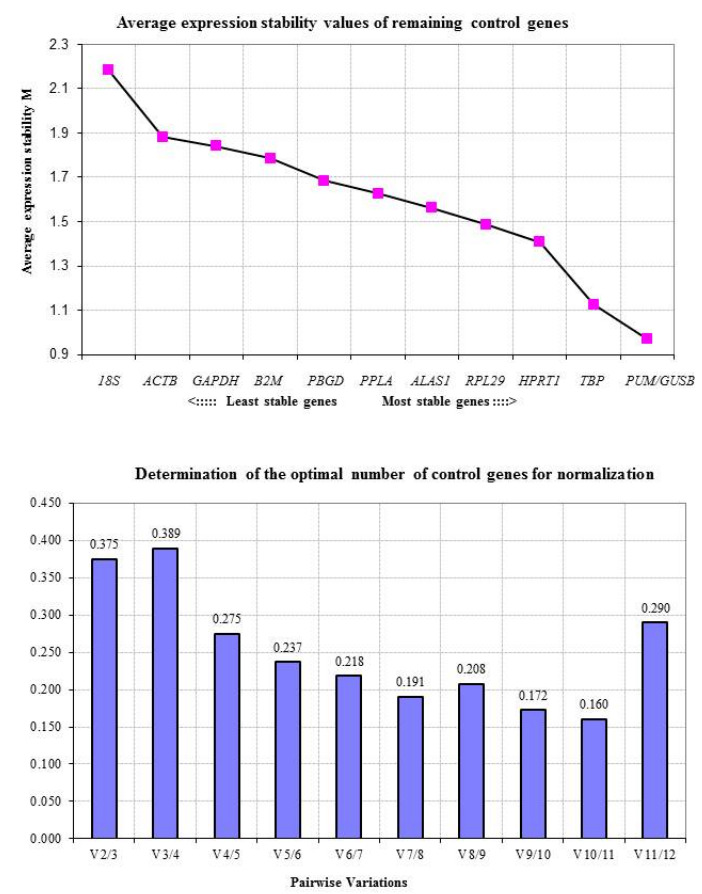

Figure 3. Reference gene stability analyzed by three programs. Comparing all five groups, two of the three algorithms determined HPRT-1 to be the most stable of the twelve genes under investigation, followed by PPIA, while the third program also showed HPRT-1 to be reliable. In contrast, according to all three applications, $18 S$, $A C T B$, and $G A P D H$, which are often used to normalize RT-qPCR data, were unreliable references. 


\section{DISCUSSION}

ANFH is a common disease but its etiology remains unclear. Recent evidence suggests that abnormalities in the bone metabolism pathway are implicated in its pathogenesis (Balla et al., 2011; Wen et al., 2012; Jiang et al., 2014).

RT-qPCR is a powerful tool allowing analysis of gene expression changes involved in ANFH. Stable reference genes should be selected in order to obtain reliable RT-qPCR results, according to the following criteria: 1) they should be expressed in target cells and tissues, and should be a basic component for transcription; 2) they should be stably expressed in all experimental environments and conditions, and their expression should not be affected by exogenous or endogenous factors; and 3) they should be expressed at levels similar to those of target genes (Bustin et al., 2005).

We included 24 subjects in this study, consisting of 20 ANFH patients of different etiologies and four donors not suffering from this condition. We isolated BMSCs from the femoral canal, and assessed 12 possible reference genes. In previous studies, $18 S, G A P D H$, and $A C T B$ have frequently been used for RT-qPCR normalization, these latter two having often been selected as reference sequences for the analysis of gene expression in BMSCs (Suzuki et al., 2000; Curtis et al., 2010).

However, the choice of these genes as references is not supported by the findings of the present study. While GAPDH and ACTB ranked highly in the control group, their stability was poor in the ANFH groups. This may be due to abnormal expression related to bone metabolism in this condition. Several studies have used musculoskeletal progenitor cells to analyze the stability of reference genes. For example, Studer et al. (2012) did so during osteogenesis, adipogenesis, and chondrogenesis of BMSCs and placenta-derived MSCs, concluding that RPL13A is a reliable and stable reference gene. Moreover, in an investigation of reference genes in BMSCs and adipose- and umbilical cord-derived MSCs, Amable et al. (2013) established the reliability and stability of B2M and RPL13A. Di et al. (2011) analyzed various bone progenitor cell lines under altered gravity conditions and strong magnetic fields, but found no suitable reference genes for such situations. However, HPRT1 and B2M demonstrated the greatest stability in osteocyte-like MLO-Y4 cells and the osteoblast-like cell line MC3T3-E1. In contrast, in human embryonic stem cells, ACTB, HPRT1, and B2M have been shown to be the least stable candidate reference genes (Willems et al., 2006).

Interestingly, we found that the most stable reference gene differed according to the etiologies of the ANFH patients from which BMSCs were isolated. We employed three programs to analyze our RT-qPCR results and identify the most reliable and stable reference gene. Although these three applications differ in the algorithms employed, two of them (BestKeeper and NormFinder) revealed that, of the genes tested, HPRT1 levels varied the least among all five groups. Thus, $H P R T 1$ is considered to be the most stable reference gene. In contrast, $18 \mathrm{~S}$ and $A C T B$ showed the most unstable expression in BMSCs. The reference sequence deemed most stable varied when ANFH groups associated with different risk factors were compared, as it did in comparisons between the control subjects and ANFH groups. Hence, researchers must choose reference genes according to the specific group under investigation. ANFH risk factors and etiologies may be confounded, in that a patient may have used corticosteroids, while having a long history of alcoholism; or may have suffered from ANFH, but only incidentally began using corticosteroids; or may have used corticosteroids many years before acquiring 
this condition. In these cases, it is particularly difficult to determine the main etiology or mechanism responsible for ANFH. Therefore, with regard to normalization of gene expression data, we recommend that HPRT1 should be chosen, followed by PPIA.

In conclusion, three programs were used to investigate the stability of 12 commonly used reference genes for the normalization of gene expression in BMSCs from ANFH patients and normal donors. Our data suggest that HPRT1 and PPIA are the most reliable reference genes of those tested, while $18 S$ and GAPDH are the least stable. Selection of the most appropriate reference sequence could help minimize inaccuracies in gene expression analysis.

\section{Conflicts of interest}

The authors declare no conflict of interest.

\section{ACKNOWLEDGMENTS}

Research supported by grants from the Jilin Provincial Department of Science and Technology (\#200705283 and \#200905164).

\section{REFERENCES}

Amable PR, Teixeira MV, Carias RB, Granjeiro JM, et al. (2013). Identification of appropriate reference genes for human mesenchymal cells during expansion and differentiation. PLoS One 8: e73792. http://dx.doi.org/10.1371/journal. pone. 0073792

Andersen CL, Jensen JL and Ørntoft TF (2004). Normalization of real-time quantitative reverse transcription-PCR data: a model-based variance estimation approach to identify genes suited for normalization, applied to bladder and colon cancer data sets. Cancer Res. 64: 5245-5250. http://dx.doi.org/10.1158/0008-5472.CAN-04-0496

Balla B, Pintér C, Kósa JP, Podani J, et al. (2011). Gene expression changes in femoral head necrosis of human bone tissue. Dis. Markers 31: 25-32. http://dx.doi.org/10.1155/2011/196021

Bustin SA, Benes V, Nolan T and Pfaffl MW (2005). Quantitative real-time RT-PCR--a perspective. J. Mol. Endocrinol. 34: 597-601. http://dx.doi.org/10.1677/jme.1.01755

Cai J, Li T, Huang B, Cheng H, et al. (2014). The use of laser microdissection in the identification of suitable reference genes for normalization of quantitative real-time PCR in human FFPE epithelial ovarian tissue samples. PLoS One 9: e95974. http://dx.doi.org/10.1371/journal.pone.0095974

Cui Q, Wang GJ and Balian G (1997). Steroid-induced adipogenesis in a pluripotential cell line from bone marrow. $J$. Bone Joint Surg. Am. 79: 1054-1063.

Curtis KM, Gomez LA, Rios C, Garbayo E, et al. (2010). EF1alpha and RPL13a represent normalization genes suitable for RT-qPCR analysis of bone marrow derived mesenchymal stem cells. BMC Mol. Biol. 11: 61. http://dx.doi. org/10.1186/1471-2199-11-61

Di S, Tian Z, Qian A, Gao X, et al. (2011). Selection of suitable reference genes from bone cells in large gradient high magnetic field based on GeNorm algorithm. Electromagn. Biol. Med. 30: 261-269. http://dx.doi.org/10.3109/15368 378.2011.608869

Grässel S, Beckmann J, Rath B, Vogel M, et al. (2010). Expression profile of matrix metalloproteinase-2 and -9 and their endogenous tissue inhibitors in osteonecrotic femoral heads. Int. J. Mol. Med. 26: 127-133. http://dx.doi.org/10.3892/ ijmm_00000444

Hernigou P and Beaujean F (1997). Abnormalities in the bone marrow of the iliac crest in patients who have osteonecrosis secondary to corticosteroid therapy or alcohol abuse. J. Bone Joint Surg. Am. 79: 1047-1053.

Hernigou P, Beaujean F and Lambotte JC (1999). Decrease in the mesenchymal stem-cell pool in the proximal femur in corticosteroid-induced osteonecrosis. J. Bone Joint Surg. Br. 81:349-355. http://dx.doi.org/10.1302/0301-620X.81B2.8818

Jiang Y, Zhang Y, Zhang H, Zhu B, et al. (2014). Pravastatin prevents steroid-induced osteonecrosis in rats by suppressing PPAR $\gamma$ expression and activating Wnt signaling pathway. Exp. Biol. Med. (Maywood) 239: 347-355. http://dx.doi. org/10.1177/1535370213519215 
Lee JS, Lee JS, Roh HL, Kim CH, et al. (2006). Alterations in the differentiation ability of mesenchymal stem cells in patients with nontraumatic osteonecrosis of the femoral head: comparative analysis according to the risk factor. $J$. Orthop. Res. 24: 604-609. http://dx.doi.org/10.1002/jor.20078

Minervini CF, Izumi M and Miki T (2009). Effect of culture conditions on reference genes expression in placenta-derived stem cells. Int. J. Stem Cells 2: 69-75. http://dx.doi.org/10.15283/ijsc.2009.2.1.69

Pfaffl MW, Tichopad A, Prgomet C and Neuvians TP (2004). Determination of stable housekeeping genes, differentially regulated target genes and sample integrity: BestKeeper--Excel-based tool using pair-wise correlations. Biotechnol. Lett. 26: 509-515. http://dx.doi.org/10.1023/B:BILE.0000019559.84305.47

Quiroz FG, Posada OM, Gallego-Perez D, Higuita-Castro N, et al. (2010). Housekeeping gene stability influences the quantification of osteogenic markers during stem cell differentiation to the osteogenic lineage. Cytotechnology 62: 109-120. http://dx.doi.org/10.1007/s10616-010-9265-1

Samara S, Dailiana Z, Chassanidis C, Koromila T, et al. (2014). Expression profile of osteoprotegerin, RANK and RANKL genes in the femoral head of patients with avascular necrosis. Exp. Mol. Pathol. 96: 9-14. http://dx.doi.org/10.1016/j. yexmp.2013.10.014

Studer D, Lischer S, Jochum W, Ehrbar M, et al. (2012). Ribosomal protein 113a as a reference gene for human bone marrow-derived mesenchymal stromal cells during expansion, adipo-, chondro-, and osteogenesis. Tissue Eng. Part C Methods 18: 761-771. http://dx.doi.org/10.1089/ten.tec.2012.0081

Suh KT, Kim SW, Roh HL, Youn MS, et al. (2005). Decreased osteogenic differentiation of mesenchymal stem cells in alcohol-induced osteonecrosis. Clin. Orthop. Relat. Res. 431: 220-225. http://dx.doi.org/10.1097/01. blo.0000150568.16133.3c

Suzuki T, Higgins PJ and Crawford DR (2000). Control selection for RNA quantitation. Biotechniques 29: 332-337.

Vandesompele J, De Preter K, Pattyn F, Poppe B, et al. (2002). Accurate normalization of real-time quantitative RT-PCR data by geometric averaging of multiple internal control genes. Genome Biol. 3: RESEARCH0034.

Wen Q, Zhou L, Zhou C, Zhou M, et al. (2012). Change in hepatocyte growth factor concentration promote mesenchymal stem cell-mediated osteogenic regeneration. J. Cell. Mol. Med. 16: 1260-1273. http://dx.doi.org/10.1111/j.15824934.2011.01407.x

Willems E, Mateizel I, Kemp C, Cauffman G, et al. (2006). Selection of reference genes in mouse embryos and in differentiating human and mouse ES cells. Int. J. Dev. Biol. 50: 627-635. http://dx.doi.org/10.1387/ijdb.052130ew 